\title{
Empathy Scores of "Ankara University School of Medicine" Fifth Year Students in Two Different Curricula; a Preliminary Report
}

\author{
Ankara Üniversitesi Tıp Fakültesinde Paralel Yürütülen Farklı Eğitim Sistemleriyle Öğrenim Gören Dönem 5 \\ Öğrencilerinin "Empati" Beceri Düzeyleri; Ön Çalıșma Raporu
}

İpek Gönüllü',Fulya Dökmeci²

'Ankara University, Faculty of Medicine, Department of Medical
Education and Informatics
2 Ankara University, Faculty of Medicine, Department of Obstetrics
\& Gynecology
\& Gynecology
Aim: In 2002 -2003 education term, Ankara University School of Medicine introduced an inte-grated student-centered curriculum composed primarily of competency-based professional skills and problem-based courses. Prior to the introduction of the new curriculum, a discipline-based, traditional curriculum was used. Both curricula ran parallel until the last class of traditionally educated students graduated in 2007. The purpose of this study was to compare the empathy scores in medical students in their fifth year in relation to their curricula.

Method: The research groups consisted of 194 fifth year students educated with a traditional curriculum and 127 fifth year students educated with the new curriculum. 'The Jefferson Scale of Physician Empathy' was used to measure the empathy scores of the students, which included 20 items with a 7-point Likert scale. t-test was used to compare the empathy scores by curricula.

Results: The results showed that the empathy scores of the traditionally educated fifth year students were significantly different when compared with fifth year students who received the student centered curriculum.

Conclusion: This study reports "preliminary data" of the probable effect of student-centered curriculum on empathy. The authors suggest that the new curriculum may improve the medical students' empathy skills. However careful interpretation is necessary for the results obtained due to the limitations of the present study.

Key Words: Empathy, Curriculum change,Medical Education,Professional Development,

\section{Self-assessment.}

Amaç: 2002-2003 Eğitim Öğretim yılında Ankara Üniversitesi Tıp Fakültesi, yeterliğe-dayalı profesyonel becerilerin ve probleme dayalı öğrenme oturumlarının olduğu, entegre, öğrenci merkezli bir müfredata geçmiștir. Bundan önceki yıllarda disipline-dayalı, geleneksel müfredat ile eğitim verilmiștir. Bu nedenle her iki müfredat, paralel olarak geleneksel müfredatla eğitim gören öğrenciler 2007 yılında mezun olana kadar devam etmiștir. Bu calıșmanın amacı, Ankara Üniversitesi Tıp Fakültesinde yürütülmekte olan iki farklı eğitim sistemi ile (klasik ve entegre) eğitim gören Dönem 5 öğrencilerinin, empati beceri düzeylerini karșılaștırmaktır.

Metot: Çalıșma grubunu 2005-2006 Eğitim-Öğretim Yılında klasik sistemle eğitim gören 194 Dönem 5 öğrencisi ve 2006-2007 Eğitim-Öğretim Yılında entegre sistemle eğitim gören 127 Dönem 5 öğrencisi olusturmaktadır. 321 öğrencinin verileri, her biri 7 dereceli 20 maddeden olusan "Jefferson Empati Skalası" ile toplanmıștır. Dönem 5 öğrencilerinin empati skorlarının farklılık gösterip göstermediğini test etmek için t-testi kullanılmıștır.

Bulgular: Bulgular, Dönem 5 öğrencilerinin empati skorlarında iki farklı eğitim sistemine göre anlamlı bir farklılık olduğunu göstermiștir.

Sonuç: Bu çalıșma, öğrenci merkezli müfredatın öğrencilerin empati skorları üzerindeki etkisini gösteren bir ön calıșma niteliğindedir. Yazarlar, yeni müfredatın öğrencilerin empati düzeylerini arttırmada etkili olabileceğini öne sürmektedirler. Fakat çalıșmanın sınırıılıkları göz önünde bulundurularak sonuçların genelleme yapmadan önce dikkatle yorumlanması gerekir. Bunun için daha iyi organize edilmiș çalıșmalara gerek vardır.

Anahtar Sözcükler: Empati, Müfredat değișimi,Tıp Eğitimi, Profesyonel Gelișim, Kendi Kendini Değerlendirme. 
Empathy, one of the elements of professionalism, improves both the quality of data obtained from the patient, and the physician's diagnostic ability enhancing both patient and physician satisfaction. In other words greater physician empathy has been associated with fewer medical errors, better patient outcomes and more satisfied patients. Practicing physicians must have professional competencies including humanism, scientific knowledge, qualified care, self-assessment, dutifulness, patient confidentiality, altruism, empathy and compassion, honesty, integrity, and ethical behavior, as well as communication. The General Medical Council (GMC) which oversees the medical education curriculum in the UK, has emphasized that demonstrating empathy represents a professional skill that makes "a good doctor" (1). Also The Accreditation Council for Graduate Medical Education (ACGME) mandates competency in 6 areas; patient care, medical knowledge, practicebased learning and improvement, professionalism, systems-based practice, and interpersonal and communication skills, which are defined as effective teaming with patients, families, and other health professionals (2). All these show that medical educators should focus on professional skills during undergraduate medical education. In order to teach professional skills, in addition to scientific knowledge and medical competencies, an effective curriculum is important for maintaining and improving those skills among medical graduates. Recent studies have reviewed the improvement and development of undergraduate and postgraduate medical education curricula, in terms of enhancing the professional skills of the graduates gained speed (3-7).
Ankara University School of Medicine (AUSM) runs a 6-year programme and developed a student-centered, problem-based, integrated curriculum in 2002-2003 (8). The traditional curriculum ended in 2006-2007. The two curricula ran parallel until the last class of traditionally educated students graduated in 2007. The traditional curriculum was a discipline-based program including lectures with large groups where professional values were transmitted by role modeling. The new curriculum emphasized small-group studies, student-centered, self-directed learning of basic and clinical science material. It was also composed of competency-based professional skills courses as well as community-based and problembased courses. Course content addresses issues related to communication, doctor-patient relations, medical ethics, cultural issues, and social elements of medicine and the value of selfawareness, self-care, and empathy.

In order to evaluate the effectiveness of this curriculum change in terms of professionalism and empathy, both formative and summative assessments are needed to use. Successful methods for measuring professionalism include selfassessment surveys, critical incident techniques, longitudinal studies, evaluation of video-taped patient visits and standardized patient-based objective structured clinical examinations (OSCEs) as presented in the recent literature (4-7, 9-11). Hojat et al. (12) have developed the Jefferson Scale of Physician Empathy (JSPE), specifically designed for measuring empathy in medical students and doctors in relation to patient care. JSPE is effective when used in selfassessment surveys for a formative assessment. They used the instrument in several studies for their psychometrics (12).
In this study JSPE survey was used to compare the empathy scores of fifth year medical students, who were educated in two different curricula (traditional curriculum and student centered, integrated curriculum), to test the following research hypothesis:

Based on the fact that empathy is the foundation of patient-doctor relationships and one of the essential components of the professional competencies in medical students, the new medical curricula would provide higher empathic score.

\section{Methods}

\section{Participants}

The study sample consisted of 194 fifth-year medical students who were educated according to the traditional curriculum during 20012006 academic years (represent $70.54 \%$ of total students) and 127 fifth-year medical students who were educated according to the new curriculum during 2002-2007 academic years (represent $92.70 \%$ of total students) at AUSM. Descriptive statistics of the students of each curriculum in terms of gender is offered in Table 1. The students' knowledge based assessment scores, do not differ in two different curricula in terms of university entrance selection criteria.

\section{Material}

The JSPE for physicians and health professionals (the "HP" version) used in this study includes 20 items (10 items positively worded and 10 items negatively worded) answered on a 7-point Likert scale $(1=$ strongly disagree, $\quad 7=$ strongly agree). Score interval is 20-140, higher the score shows higher empathic consistency.

The "HP-version" was developed by slightly modifying the wording of 
the "S-version" to make it more relevant to the caregiver's empathetic behavior rather than to the students' empathetic orientation or perceptions (13).

The "HP" version of JSPE was translated into Turkish using "back translation" procedure which was recommended by authors, and validity-reliability studies were done by Malkondu (2006: unpublished ). The patterns of findings that Malkondu has received are those Hojat et al. also reported for samples in the United States (10). Hojat has mentioned Malkondu in his book (10, page 111)

\section{Procedures}

Ethics Committee of Ankara University School of Medicine approved the study design and proposal.

The empathy scale was completed voluntarily by all participants during their last clerkship rotation, similar to the one completed before the internship began in May. The empathy scores of each student were obtained in terms of sums of each 20 JSPE items of the empathy scale. The statistical Package for the Social Sciences for Windows (SPSS) was used to analyze the data.

The difference between the empathy scores of fifth year students in terms of different curricula was analyzed with t-test.

\section{Results}

Means and standard deviations of empathy scores of fifth-year medical students in two different curricula are $105.12 \pm 14.42$, and $108.61 \pm 13.19$ respectively (offered in Table 2).

Analysis showed that the fifth year students' empathy scores in two curricula were significantly different $[\mathrm{t}(319)=2.19, \mathrm{p}<0.05]$ (offered in Table 3 ).

\section{Discussion}

Empathy is the physician's ability to cognitively recognize a patient's perspectives and experiences, and convey such an understanding back to the patient (12). It is one of the expected outcomes of medical education and an ability that medical school alumni must have. In this study a significant difference was found between the students' empathy scores in two different curricula. The mean empathy score for the students from the traditional curriculum was found 105.12 and the mean empathy score for the students from the integrated, student centered curriculum was found 108.61. By comparison, Hojat et al (12) showed that the mean empathy scores of third year medical students was 118 and the residents was 118 (12), while the mean empathy scores for physicians was 120 (13). The mean empathy scores of our students are low, and we suggest that our students need more instructional support in emphatic attitudes and that the new curriculum needs improvement to increase the students' professional skills by implementing new innovative educational techniques.

Several studies suggest that a small group session like problem-based learning (PBL) contributes in significant ways to the development of professional competencies. PBL students have better interpersonal competencies, which positively affects the quality of their interactions with patients (3, 14, 15). Antepohl et al. (14) reported that medical graduates of a PBL curriculum felt especially well prepared in terms of communication skills with patients, collaboration with other health professionals and development of critical thinking / scientific attitudes (14). One way to preserve and enhance empathy

Table 1. Descriptive statistics for completers

\begin{tabular}{|c|c|c|c|c|c|c|c|}
\hline \multirow{2}{*}{ Curriculum } & \multicolumn{2}{|c|}{ Female } & \multicolumn{2}{|c|}{ Male } & \multicolumn{2}{|c|}{ Total } & \multirow[b]{2}{*}{$p$} \\
\hline & $\mathrm{n}$ & $\%$ & $\mathrm{n}$ & $\%$ & $\mathrm{n}$ & $\%$ & \\
\hline Traditional & 110 & 56.7 & 84 & 43.3 & 194 & 100 & 21 \\
\hline Student centered & 81 & 63.8 & 46 & 36.2 & 127 & 100 & 0.21 \\
\hline
\end{tabular}

Table 2. Means and standard deviations of the JSPE scores of fifth-year medical students by different curricula.

\begin{tabular}{|c|c|c|c|c|c|c|}
\hline \multirow[b]{2}{*}{ Curriculum } & \multirow[b]{2}{*}{$\mathrm{n}$} & \multicolumn{5}{|c|}{ Empathy scores } \\
\hline & & Mean & SD & Median & Min. & Max. \\
\hline Traditional & 194 & 105.12 & 14.42 & 106.00 & 58 & 134 \\
\hline Student centered & 127 & 108.61 & 13.19 & 110.54 & 77 & 132 \\
\hline
\end{tabular}

Table 3. T-test results of the JSPE scores of fifth-year medical students by different curricula

\begin{tabular}{|l|l|l|l|l|l|l|}
\hline Curriculum & $\mathbf{N}$ & $\bar{X}$ & $\mathbf{S}$ & $\mathbf{s d}$ & $\mathbf{t}$ & $\mathbf{p}$ \\
\hline Traditional & 194 & 105.12 & 14.42 & \multirow{2}{*}{319} & 2.19 & 0.029 \\
\hline Student centered & 127 & 108.61 & 13.19 & & \\
\hline
\end{tabular}


among medical students is to teach and rol-model it during school (16). In the study of Tavakol et al. (17) students predominantly agreed that empathy needs to be taught as a skill. Empathic ability was identified as an important innate attribute which nevertheless can be enhanced by educational interventions (17). In a review of empathy training, experimental learning methods, including rolplay, case scenario-based activities, PBL and simulation, were shown to improve empathic ability in nurses (18). Also Cunico et al. (19) showed that specific training course, including seminars and laboratories in small groups with tutors, aimed at learning and developing communicative and empathic abilities, is effective in nursing students (19). The results of Prince et al's study (5) showed that PBL enhances the level of skill displayed in general competencies such as communication skills and teamwork (5). The study by Koh and colleagues (20) systematically reviewed all of the studies in medicine linking problem-based learning to outcomes. They showed that only four competencies had moderate to strong levels of evidence in support of problem-based learning for both self- and observed assessments: coping with uncertainty (strong), appreciation of legal and ethical aspects of health care (strong), communication skills (moderate and strong respectively) and selfdirected continuing learning (moderate). They interpred that Problem-based learning during medical school has positive effects on physician competency after graduation, mainly in social and cognitive dimensions (20). According to Peters et al.'s (21) research, PBL curriculum alumni rated their preparation to practice medicine in a humane fashion more highly than did graduates of its conventional curriculum and expressed more confidence in their ability to manage patients with psychosocial problems (21). Graduates of the PBL curriculum showed higher self-ratings on communication skills in dealing with the social context of patients (7).

PBL activities enable students to practice the professional skills (interpersonal communication, problem-solvers, self-directed, lifelong learning) while still in an educational environment. Graduates of PBL curricula should therefore be better prepared to respond to the challenges of professional practice than graduates of conventional curricula. Formal teaching alone is not enough to ensure that students will develop into competent and responsible doctors. Today, personal and professional development needs behavior change which results from a number of influences including education, feedback, rewards, penalties and participation (22). In order to gain these behaviors and attitudes, different educational and evaluation methods must be restructured and integrated to the curriculum. The traditional method of transmitting professional values by role modeling is no longer adequate. Professionalism must be taught explicitly and evaluated effectively (23). Our faculty curriculum development program, started in 2002-2003 designed to support the teaching and evaluation of professionalism which it supported throughout the students' early clinical work. Lifelong learning is fostered by using student centered methods like PBL and Competency Based Learning. This program is intended to lead to selfreported changes in teaching and practice as well as new educational initiatives.

\section{Limitations}

One of the limitations of our study is that we should have used a pretest- posttest control group design for such a comparative study. The JSPE, should have been administered prior to the start of each curriculum to each group of students who participate in the traditional and the new curriculum (pretest), and then to both groups after completion of the program (posttest). In order to show a significant difference in empathy scores in the favor of the group who were trained under the new curriculum, it could have been confirmed with this defined method. However since the traditional group of the study was in their fifth year, and the other group was in their forth year, we would not have had the chance to do the pretests.

A more appropriate way to measure empathy among medical student is the student version (S-Version) of the JSPE, not the Health Profession version (HP-Version) used in this study since the students were at the end of their fifth year, before starting their internship, however the Turkish translation of the S-version was not available.

Another limitation of our study is the evaluation technique which is based on self-assessment. Although self-assessment does not always provide objective information, it is more reliable than asking experts or colleagues (24). As recent studies suggest, it is the patient who can tell us whether a medical student or doctor demonstrates empathy in a particular situation. To use instruments that measure empathic response from the patient's perspective may be more valuable in terms of objective assessment (25), such as observing and rating student's attitudes during an intervention with a real patient or with Standardized Patients (SPs). Van Zanten et al showed that using standardized patients to evaluate some professional attributes, such as empathy and respect, are also 
effective to improve the medical students' empathy skills (9).

\section{Conclusion}

This study reports "preliminary data" of curriculum change (from discipline-based, traditional one to integrated, student -centered) effects on empathic perception of medical students. Besides the new curriculum, we suggest that a new communication skills program should be prepared and it may be beneficial for improving the medical students' empathy skills and may have a positive effect on the empathy scores.

\section{REFERENCES}

1. General Medical Council., Retrieved from http://www.gmcuk.org/guidance/ethical_guidance/716 2.asp, and http://www.gmcuk.org/guidance/good_medical_practi ce/good_doctors.asp, Accessed September 17, 2012.

2. Accreditation Council for Graduate Medical Education. ACGME General Competencies and Outcomes Assessment for Designated Institutional Officials. Retrieved from http://www.acgme.org/ acWebsite/irc/irc_competencies.asp. Accessed September 17, 2012.

3. Schmidt HG, Van Der Molen HT. Selfreported competency ratings of graduates of a problem-based medical curriculum. Acad Med 2001;76:466468.

4. Schmidt HG, Vermeulen L, Van Der Molen HT. Longterm effects of problem-based learning: a comparison of competencies acquired by graduates of a problem-based and a conventional medical school. Med Educ 2006;40:562-567.

5. Prince KJAH, Van Eijs WLJ, Boshuizen HPA, Van Der Vleuten CPM, Scherpbier AJJA. General competencies of problem-based learning (PBL) and non-PBL graduates. Med Educ 2005;39:394-401.

6. Hook KM, Pfeiffer CA. Impact of a new curriculum on medical students'
We also need further well-designed studies to justify that the new curriculum provides a positive effect on the students' empathy skills. Further studies should be done periodically to assess the students' communication skills and to see their developments.

\section{Acknowledgment}

The authors wish to thank Mohammadreza Hojat, for his helpful comments on earlier versions of this article, to Atilla Elhan for his helpful comments on the statistical analyses of the data, and Judy Thornton for her

interpersonal and interviewing skills. Med Educ 2007;41:154-159.

7. Cohen-Schotanus J, Muijtjens AMM, SchoőNrock-Adema J, Geertsma J, Van Der Vleuten CPM. Effects of conventional and problem-based learning on clinical and general competencies and career development. Med Educ 2008;42:256-265.

8. Kemahli S, Dokmeci F, Palaoglu O, et al. How we derived a core curriculum: from institutional to national-Ankara University experience. Medical Teacher 2004;26:295-298.

9. Van Zanten M, Boulet RJ, Norgini JJ, Mckinley D. Using a stardardised patient assessment to measure professional attributes. Med Educ 2005;39:20- 29.

10. Hojat M. Empathy in Patient Care: Antecedents, Development, Measurement, and Outcomes. The Jefferson Scale of Physician Empathy. Springer Publications;2006. p. 87-115.

11. Newton BW, Barber L, Clardy J, Clevland E, O'Sullivan P. Is There Hardening of the Heart During Medical School? Acad Med 2008;83:244-249.

12. Hojat M, Mangione S, Cohen MJM, et al. The Jefferson Scale of Physician Empathy: development and preliminary psychometric data. EPM 2001;61:349-365. contribution of the final grammar review of the article.

The authors presented this study at The Association for Medical Education in Europe CongressAMEE 2008, in Prague, Czech Republic as a short communication.

It was also presented at the $5^{\text {th }}$ Turkish National Medical Education Congress, 2008, in Izmir, Turkey as a poster presentation.

13. Hojat M, Gonnella JS, Nasca TJ, et al empathy: definition, measurement, and relationship to gender and specialty. AmJ Psychiatry 2002;159:1563-1569.

14. Antepohl W, Domeij E, Forsberg P, Ludvigsson J. A follow-up of medical graduates of a problem based learning curriculum, Med Educ 2003;37:155162.

15. Hoffmann K, Hosokawa M, Blake RJR, Headrick L, Johnson G. Problem-based learning outcomes: ten years of experience at the University of Missouri - Columbia School of Medicine. Acad Med, 2006;81:617-625.

16. Crandall SJ, Marion GS. Commentary: identifying attitudes towards empathy: an essential feature of professionalism. Acad Med 2009;84:1174-6.

17. Tavakol S, Dennick R, Tavakol M. Medical students' understanding of empathy: a phenomenological study. Med Educ 2012;46:306-316

18. Brunero S, Lamont S, Coates M. A review of empathy education in nursing. Nurs Inq 2010;17:65-74

19. Cunico L, Sartori R, Marognolli $O$ and Meneghini AM. Developing empathy in nursing students: a cohort longitudinal study. J Clin Nurs 2012:21, 2016-2025 
20. Gerald Choon-Huat Koh GC-H, Hoon Eng Khoo HE, Mee Lian Wong ML, David Koh D. The effects of problembased learning during medical school on physician competency: a systematic review CMAJ 2008;178:34-41

21. Peters AS, Greenberger-Rosovsky RG, Crowder C, Block SD, Moore GT. Long-term Outcomes of the New Pathway Program at Harvard Medical
School: A Randomized Controlled Trial. Acad Med 2000;75:470-479.

22. Gordon J. Fostering students' personal and professional development in medicine; a new framework for PPD. Med Educ 2003;37:341-349.

23. Steinert Y, Cruess S, Cruess R, Snell L. Faculty development for teaching and evaluating professionalism: from programme design to curriculum change. Med Educ 2005;39:127-136.
24. Van Loo J, Semeijn J. Defining and measuring competences: an application to graduate surveys. Qual \& Quant 2004;38:331-349.

25. Spencer J. Decline in empathy in medical education: how can we stop the rot? Med Educ 2004;38:916-920. 